\title{
Faktor-faktor Penyebab Ketidaklengkapan Pengisian Rekam Medis Dokter di Ruang Rawat Inap RSI Unisma Malang
}

\section{Factors Affecting Incomplete Physicians' Medical Record Filling at Unisma Islamic Hospital Malang}

\author{
Cicilia Lihawa ${ }^{1}$, Muhammad Mansur ${ }^{1}$, Tri Wahyu $S^{2}$ \\ ${ }^{1}$ Program Studi Magister Manajemen Rumah Sakit Fakultas Kedokteran Universitas Brawijaya Malang \\ ${ }^{2}$ Rumah Sakit Islam Unisma Malang
}

\begin{abstract}
Ketidaklengkapan pengisian rekam medis di RSI Unisma Malang menggambarkan pelayanan kesehatan yang diberikan dan mutu pelayanan rekam medis. Salah satu indikator mutu pelayanan di unit rekam medis adalah kelengkapan pengisian rekam medis setelah pelayanan. Adanya ketidaklengkapan pengisian rekam medis setelah selesai pelayanan di ruang rawat inap RSI Unisma Malang perlu dicari penyebab dan solusinya. Pendekatan deskriptif dilakukan dengan metode studi dokumen, observasi unit pelayanan, dan kuesioner yang telah dilakukan uji validitas dan reliabilitas dengan tambahan pertanyaan terbuka untuk saran. Sampel dalam penelitian ini adalah dokter sejumlah 27 orang. Penentuan akar masalah menggunakan diagram fishbone, yang kemudian di tentukan salah satu menjadi prioritas masalah menggunakan metode USG (Urgency, Seriousness, and Growth) dan penetapan solusi dengan tapisan McNamara. Hasil menunjukkan peran faktor susunan form RM yang kurang sistematis dalam ketidaklengkapan pengisian rekam medis. Sebagai solusi untuk meningkatkan kelengkapan pengisian rekam medis adalah dengan membuat rancangan form rekam medis terintegrasi.
\end{abstract}

Kata Kunci: Dokter, ketidaklengkapan rekam medik, rawat inap

\begin{abstract}
Incomplete filling of medical records at Unisma Islamic Hospital describes the health service provided and the medical record service quality. One indicator of quality care in medical record unit is the completeness of medical records after service completion. The causes and solutions of the presence of incomplete filling of medical records after service completion in the inpatient unit of Unisma Islamic Hospital Malang are necessary to be found. This research is a descriptive study by using document study method, observing service units, and giving questionnaire which its validity and reliability has been tested and added open question for suggestions. The samples in this research were 27 physicians. Determination the root of the problem was using fishbone diagram, continued by specifying one of the main problems using USG (Urgency, Seriousness, and Growth) and then found out the solutions using Mc Namara theory. The result of this research show a relationship between unsystematic composition of the medical record form and incomplete filling of medical records. A solution to improve the completeness of medical records is to create an integrated medical record draft form.
\end{abstract}

Keywords: Incomplete medical records, inpatient unit, physician

Jurnal Kedokteran Brawijaya, Vol. 28, Suplemen No. 2, 2015; Korespondensi: Cicilia Lihawa. Program Studi Magister Manajemen Rumah Sakit Fakultas Kedokteran Universitas Brawijaya Malang, Jl. Veteran Malang 65145 Tel. (0341) 569117 Email: lyariaachamar@yahoo.co.id 


\section{PENDAHULUAN}

Rumah sakit merupakan bagian penting dari sistem kesehatan yang menyediakan pelayanan kuratif komplek, gawat darurat, pusat alih pengetahuan dan teknologi, dan berfungsi sebagai pusat rujukan. Untuk meningkatkan kepuasan pemakai jasa, rumah sakit harus senantiasa meningkatkan mutu pelayanan sesuai dengan harapan pelanggan yang dapat dilakukan melalui peningkatan kualitas kerja. Mutu layanan merupakan suatu hal yang sangat penting untuk tetap dapat menjaga keberadaan suatu rumah sakit (1).

Pelayanan yang bermutu bukan hanya pada pelayanan medis saja, tetapi juga pada pelayanan penunjang seperti penanganan rekam medis (RM) di rumah sakit yang menjadi salah satu indikator mutu pelayanan rumah sakit yang dapat diketahui melalui kelengkapan pengisian rekam medis (2). Salah satu parameter untuk menentukan mutu pelayanan kesehatan di rumah sakit adalah data atau informasi dari rekam medis yang baik dan lengkap. Indikator mutu rekam medis yang baik dan lengkap adalah kelengkapan isi, akurat, tepat waktu dan pemenuhan aspek persyaratan hukum.

Rekam medis memuat informasi yang cukup dan akurat tentang identitas pasien, perjalanan penyakit selama pasien berada di rumah sakit. Rekam medis harus berisi informasi lengkap perihal proses pelayanan di masa lalu, masa kini dan perkiraan yang terjadi dimasa mendatang. Catatan pada RM yang baik dan lengkap sangat berguna untuk mengingatkan dokter dengan keadaan, hasil pemeriksaan dan pengobatan yang telah diberikan kepada pasien. Hal ini berguna untuk memudahkan strategi pengobatan pasien (3).

Berdasarkan keputusan menteri kesehatan nomor 129/Menkes/SK/II/2012, Standar Pelayanan Minimum (SPM) rumah sakit menjadi acuan akreditasi yang harus dilaksanakan oleh semua rumah sakit untuk dapat meningkatkan mutu pelayanan di rumah sakit (4). Setiap unit pelayanan dan manajemen rumah sakit telah ada SPM yang harus dipenuhi.

Kinerja rumah sakit bisa diukur dari capaian pelaksanaan SPM. Berdasarkan indikator SPM pada RSI Unisma Malang ditemukan beberapa permasalahan yang saat ini dihadapi. Dari 17 jenis layanan dan 131 indikator SPM RSI Unisma Malang, terdapat 13 indikator pelayanan $(9,9 \%)$ yang belum terukur, $75,6 \%$ indikator pelayanan yang tercapai dan 19 indikator pelayanan (14,5\%) yang belum tercapai.

Salah satu Indikator pelayanan yang belum tercapai terdapat di pelayanan Rekam Medis, yaitu kelengkapan pengisian rekam medis 24 jam setelah selesai pelayanan hanya sebesar $50 \%$ dari standar $100 \%$. Ketidaklengkapan pencatatan pengisian rekam medis akan mempengaruhi mutu pelayanan rekam medis yang akan menggambarkan pelayanan kesehatan yang diberikan. Menurut Wirawan untuk meningkatkan mutu rekam medis ada 3 unsur yaitu: Kelengkapan isi rekam medis,validitas (kesahihan) dan sanksi (5).

Rekam medis menurut Pasal 1 ayat 1 Permenkes No.269/Menkes/Per/III/2008 dan Pasal 46 ayat 1 UU Praktik Kedokteran tahun 2004 tentang rekam medis adalah berkas yang berisikan catatan dan dokumen tentang identitas pasien, pemeriksaan, pengobatan, tindakan dan pelayanan lain kepada pasien pada sarana pelayanan kesehatan (6). Setiap catatan rekam medis harus dibubuhi nama, waktu, dan tanda tangan petugas yang memberikan pelayanan atau tindakan. Tujuan dilaksanakannya rekam medis adalah untuk menunjang tercapainya tertib administrasi rumah sakit agar berhasil sebagaimana yang diharapkan. Tertib administrasi merupakan salah satu faktor yang menentukan dalam upaya pelayanan kesehatan yang bermutu di rumah sakit.

Kelengkapan rekam medis sangat bermanfaat untuk mengetahui secara detail riwayat penyakit pasien, tindakan pemeriksaan yang telah dilakukan, dan merencakan tindakan selanjutnya. Diagnosis penyakit yang ditetapkan oleh seorang dokter, akan sangat mempengaruhi tindakan terhadap pasien baik dalam pengobatan atau bahkan tindakan yang akan diambil. Suatu diagnosa yang akurat didasari oleh anamnesa, pemeriksaan fisik, pemeriksaan penunjang dan ditulis dalam berkas rekam medis (7). Rekam medis digunakan sebagai pedoman atau perlindungan hukum yang mengikat karena di dalamnya terdapat segala catatan tentang tindakan, pelayanan, terapi, waktu terapi, tanda tangan dokter yang merawat, tanda tangan pasien yang bersangkutan, dan lain-lain. Kegunaan utama rekam medis dapat ditinjau dari beberapa asek yaitu: aspek administrasi, aspek medis, aspek hukum, aspek keuangan, aspek penelitian, aspek pendiidikan dan aspek dokumentasi (8).

Dokter yang merawat, petugas rekam medis, pimpinan rumah sakit dan staf medik mempunyai tanggung jawab terhadap rekam medis tetapi tanggung jawab utama akan kelengkapan rekam medis terletak pada dokter yang merawat pasien tersebut (9). Ketidaklengkapan pengisian rekam medis membuat terhambatnya pemenuhan hak pasien terhadap isi rekam medisnya, mempersulit proses klasifikasi dan kodefikasi penyakit, terhambatnya proses pembuatan pelaporan rumah sakit, terhambatnya pembuatan tanda bukti untuk kasus kepolisian dan hukum, dan menghambat proses pengajuan klaim asuransi. Ketidaklengkapan pengisian rekam medis mempengaruhi mutu pelayanan rekam medis dan berdampak pada kesinambungan pelayanan dan keselamatan pasien karena belum tergambarnya tanggung jawab dokter dalam informasi rekam medis. Ketidaklengkapan pengisian dokumen rekam medis oleh dokter yang melakukan tindakan medis dapat disebabkan rendahnya motivasi atau kinerja dokter dalam melaksanakan pekerjaannya.

Proses kegiatan penyelenggaraan rekam medis dimulai saat diterimanya pasien di rumah sakit, dilanjutkan dengan kegiatan pencatatan data medis pasien oleh dokter atau tenaga kesehatan lain yang memberikan pelayanan secara langsung. Rekam medis harus segera dilengkapi setelah pasien menerima pelayananan. Kelengkapan pengisian rekam medis pasien rawat inap yaitu dalam waktu $\leq 24$ jam setelah pasien rawat inap diputuskan untuk pulang yang meliputi identitas pasien, anamnesis, rencana asuhan, pelaksanaan asuhan, tindak lanjut dan resume (10). Penelitian ini dilakukan untuk mengidentifikasi faktor-faktor penyebab ketidaklengkapan pengisian rekam medis dokter setelah selesai pelayanan di ruang rawat inap RSI Unisma Malang dan kemudian mencari alternatif solusinya. 


\section{METODE}

Penelitian dilakukan secara deskriptif untuk mengidentifikasi faktor-faktor penyebab ketidak lengkapan pengisian rekam medis setelah selesai pelayanan di ruang rawat inap RSI Unisma Malang. Metode yang digunakan adalah observasi unit pelayanan dan kuesioner. Kuesioner dibagikan kepada dokter yang bertanggung jawab di ruang rawat inap. Penelitian dilakukan di instalasi rawat inap RSI Unisma Malang pada tanggal 3-18 Oktober 2014. Sampel penelitian adalahsebanyak 27 orang terdiri dari dokter umum dan dokter spesialis. Teknik sampling dilakukan dengan cara purposive sampling, yaitu pengambilan sampel secara sengaja sesuai dengan persyaratan sampel yang diperlukan.

Pertanyaan pada kuesioner diambil dari penelitian terdahulu meliputi aspek man, management, machine, material (11). Pertanyaan pada kuesioner merupakan pertanyaan tertutup. Opsi jawaban terdiri dari jawaban "ya" dan "tidak". Terdapat pertanyaan terbuka mengenai informasi, saran, dan masukan terhadap ketidak lengkapan pengisian dokumen rekam medis di ruang rawat inap. Penentuan akar masalah menggunakan diagram fishbone yang melibatkan unit rekam medis, terdiri 4 orang, ditentukan beberapa masalah menjadi akar permasalahan dengan diskusi, dan kemudian di tentukan salah satu menjadi prioritas masalah menggunakan metode skoring USG (Urgency, Seriousness, and Growth) untuk kemudian di cari alternatif solusinya dengan teori tapisan Mc Namara.

\section{HASIL}

Berdasarkan hasil analisa data survei penelitian yang telah dilakukan menunjukkan faktor penyebab ketidak lengkapan pengisian rekam medis sebagaimana disajikan pada Tabel 1. Faktor komunikasi merupakan faktor terbanyak yang dilaporkan sebagai penyebab ketidak lengkapan RM. Dari faktor penyebab ketidak lengkapan pengisian rekam medis tersebut didapatkan beberapa akar permasalahan yaitu: kurang adanya sosialisasi mengenai Standar Prosedur Operasional (SPO) dan kebijakan tentang RM terutama kepada para dokter spesialis, ada beberapa orang dokter yang belum mengetahui bahwa pengisian kelengkapan $\mathrm{RM} \leq 24$ jam setelah pasien rawat inap diputuskan pulang, susunan form RM kurang sistematis, dokter tidak mengetahui apakah terdapat wadah komunikasi antara dokter dengan manajemen penunjang medik, rapat membahas kelengkapan dokumen rekam medis tidak berjalan efektif, dan para dokter spesialis merasa tidak dilibatkan dalam rapat tersebut, kepala ruangan tidak selalu mengingatkan dokter.

Setelah mengidentifikasi beberapa akar masalah maka langkah berikutnya adalah memilih masalah dengan cara melakukan skala prioritas masalah. Pada tahap ini masingmasing masalah dinilai tingkat risiko dan dampaknya apabila tidak dilakukan intervensi serta seberapa besar usaha dibutuhkan apabila perbaikan akan dilakukan. Metode skoring yang digunakan adalah metode USG (Urgency, Severity, and Growth). Bila telah didapatkan jumlah (skor) maka dapat menentukan prioritas masalah (12). Langkah skoring dengan menggunakan metode USG adalah membuat daftar akar masalah,membuat tabel matrik prioritas masalah dengan bobot skoring 1-5 dan nilai yang tertinggi sebagai prioritas masalah. Didapatkan susunan form RM kurang sistematis sebagai akar masalah.

Tabel 1. Faktor penyebab ketidaklengkapan pengisian rekam medis

\begin{tabular}{|c|c|c|c|}
\hline No & Fishbone & Variabel & Hasil \\
\hline \multirow[t]{4}{*}{1.} & Man & Pengetahuan & $\begin{array}{l}18,51 \% \text { responden ( } 5 \text { orang) belum mengetahui bahwa pengisian kelengkapan } \mathrm{RM} \leq 24 \text { jam setelah } \\
\text { pasien pulang }\end{array}$ \\
\hline & & Motivasi & $3,70 \%$ (1 orang) tidak mengetahui dampak dari ketidaklengkapan dokumen RM \\
\hline & & & $11,11 \%$ (3 orang) menyatakan tidak mengetahui manfaat dan kegunaan RM \\
\hline & & & $\begin{array}{l}22,22 \% \text { ( } 6 \text { orang) menyatakan bahwa kepala ruangan tidak selalu mengingatkan dokter untuk melengkapi } \\
\text { dokumen rekam medis }\end{array}$ \\
\hline \multirow[t]{3}{*}{2.} & Management & Prosedur kerja & $37,03 \%$ responden (10 orang) menyatakan tidak mengetahui apakah terdapat SPO tentang RM. \\
\hline & & & 70,77\% responden (19 orang) menyatakan tidak ada sosialisasi mengenai SPO RM. \\
\hline & & & $55,55 \%$ responden (15 orang) menyatakan tidak ada evaluasi tentang pelaksanaan prosedur kerja \\
\hline \multirow[t]{5}{*}{3.} & Machine & Komunikasi & $\begin{array}{l}37,63 \% \text { responden tidak mengetahui apakah terdapat wadah komunikasi antara dokter dengan } \\
\text { manajemen penunjang medic. }\end{array}$ \\
\hline & & & $\begin{array}{l}77,77 \% \text { responden ( } 21 \text { orang) menyatakan bahwa rapat membahas kelengkapan dokumen rekam medis } \\
\text { tidak berjalan efektif dan para dokter spesialis merasa tidak dilibatkan didalamnya sebanyak 59,25 \% ( } 16 \\
\text { orang) menyatakan bahwa mereka tidak mendapat penjelasan yang intens tentang dokumen rekam } \\
\text { medis. }\end{array}$ \\
\hline & & Kepemimpinan & $\begin{array}{l}44,44 \% \text { responden (12orang) menyatakan bahwa dalam mengatasi masalah ketidaklengkapan dokumen } \\
\text { rekam medis, manajemen penunjang medik tidak meminta masukan dari dokter dan mengambil } \\
\text { keputusan berdasarkan keputusan tersebut. }\end{array}$ \\
\hline & & Pengendalian & $\begin{array}{l}\text { 44,44\% responden ( } 12 \text { orang) menyatakan tidak mengetahui apakah terdapat bentuk evaluasi pada } \\
\text { dokter mengenai kelengkapan dokumen rekam medis }\end{array}$ \\
\hline & & & $\begin{array}{l}44,44 \% \text { responden ( } 12 \text { orang) menyatakan tidak ada pelaporan secara rutin tentang ketidaklegkapan } \\
\text { dokumen rekam medis kepada unit rawat inap. }\end{array}$ \\
\hline 4. & Material & & $\begin{array}{l}44,44 \% \text { responden ( } 12 \text { orang) menyatakan bahwa susunan form RM kurang sistematis, dan tidak adanya } \\
\text { ruang khusus untuk melengkapi dokumen RM }\end{array}$ \\
\hline 5. & Money & & Sumber dana yang terbatas untuk mendukung kelengkapan rekam medis \\
\hline
\end{tabular}


Tabel 2. Penentuan prioritas masalah menurut metode USG

\begin{tabular}{|c|c|c|c|c|c|c|}
\hline \multirow{2}{*}{ No } & \multirow{2}{*}{ Daftar Akar Permasalahan } & \multicolumn{3}{|c|}{ Kriteria } & \multirow{2}{*}{ Total } & \multirow{2}{*}{ Ranking } \\
\hline & & $\mathbf{U}$ & $\mathbf{S}$ & G & & \\
\hline 1 & Kurang adanya sosialisasi mengenai & & & & & \\
\hline & $\begin{array}{l}\text { SPO dan Kebijakan tentang RM } \\
\text { terutama kepada para Dokter } \\
\text { spesialis }\end{array}$ & 3 & 2 & 2 & 7 & 4 \\
\hline 2 & $\begin{array}{l}\text { Beberapa orang dokter yang belum } \\
\text { mengetahui bahwa pengisian } \\
\text { kelengkapan } \mathrm{RM} \leq 24 \text { jam setelah } \\
\text { pasien rawat inap diputuskan pulang }\end{array}$ & 4 & 4 & 3 & 11 & 2 \\
\hline 3 & Susunan form RM kurang sistematis & 4 & 4 & 4 & 12 & 1 \\
\hline 4 & $\begin{array}{l}\text { Dokter tidak mengetahui apakah } \\
\text { terdapat wadah komunikasi antara } \\
\text { dokter dengan manajemen } \\
\text { penunjang medik }\end{array}$ & 2 & 2 & 2 & 6 & 5 \\
\hline 5 & $\begin{array}{l}\text { Rapat membahas kelengkapan } \\
\text { dokumen rekam medis tidak berjalan } \\
\text { efektif dan para dokter spesialis } \\
\text { merasa tidak dilibatkan dalam rapat } \\
\text { tsb }\end{array}$ & 3 & 3 & 3 & 9 & 3 \\
\hline 6 & $\begin{array}{l}\text { Kepala ruangan tidak selalu } \\
\text { mengingatkan dokter }\end{array}$ & 3 & 3 & 3 & 9 & 3 \\
\hline
\end{tabular}

\section{AlternatifSolusi}

Setelah prioritas akar masalah ditentukan maka langkah selanjutnya adalah mencari alternatif solusi. Akar masalah adalah pada susunan form yang kurang sistematis. Alternatif solusi yang didapatkan yaitu: membuat pemisahan warna dalam form dan membuat rancangan form RM yang terintegrasi. Selanjutnya memilih alternatif solusi dengan menggunakan metode Mc Namaradengan menentukan 3 kriteria yang dinilai dari setiap alternatif yaitu kontribusi, kemurahan, dan kelayakan. Tiap kriteria diberikan skor nilai antara 1-5. total skor tertinggi adalah solusi permasalahan yang dipilih (13). Dari Tabel 3 maka dapat diketahui bahwa prioritas alternatif solusi adalah membuat rancangan form RM yang terintegrasi.

Tabel 3. Tapisan alternatif solusi Mc.Namara

\begin{tabular}{llccccc}
\hline No & Alternatif Solusi & Efektifitas & $\begin{array}{c}\text { Efisiensi } \\
\text { (biaya) }\end{array}$ & Kemudahan & Total Ket. \\
\hline 1 & $\begin{array}{l}\text { Membuat rancangan } \\
\text { form RM yang } \\
\text { terintegrasi }\end{array}$ & 4 & 3 & 2 & 9 & 1 \\
2 & $\begin{array}{l}\text { Membuat pemisahan } \\
\text { warna dalam form RM }\end{array}$ & 3 & 2 & 2 & 7 & 2 \\
\hline
\end{tabular}

\section{DISKUSI}

Ketidaklengkapan pengisian rekam medis menggambarkan pelayanan kesehatan yang diberikan dan mutu pelayanan rekam medis. Kelengkapan pengisian

\section{DAFTAR PUSTAKA}

1. Lubis E. Pengaruh Karakteristik Individu dan Motivasi Intrinsik terhadap Kinerja Dokter dalam Kelengkapan Pengisian Rekam Medis Pasien Rawat Inap di Rumah Sakit PT Perkebunan Nusantara IV (PERSERO) Tahun 2008. [Tesis]. Universitas Sumatera Utara, Medan. 2009. rekam medis 24 jam setelah selesai pelayanan di RSI Unisma yaitu sebesar $50 \%$ dari standar $100 \%$. Kelengkapan pengisian rekam medis pasien rawat inap yaitu dalam waktu $\leq 24$ jam setelah pasien rawat inap diputuskan untuk pulang yang meliputi identitas pasien, anamnesis, rencana asuhan, pelaksanaan asuhan, tindak lanjut, dan resume. Temuan utama dalam penelitian ini adalah susunan form RM yang kurang sistematis, sebanyak $44,44 \%$ responden ( 12 orang) menyatakan bahwa susunan form RM masih kurang sistematis sehinga sering menyulitkan dalam pengisiannya.Berdasarkan penelitian oleh Mawarni dan Wulandari penyebab ketidaklengkapan pengisian rekammedis di instalasi rawat inap RS Muhammadiyah Lamongan adalah tidak adanya pelaksanaan monitoring sehingga proses pengisian rekam medis dengan lengkap tidak bisa dikendalikan (14). Penelitian Rahmadani mengidentifikasifaktor penyebab ketidaklengkapan dokumen rekam medis pasien rawat inap adalah oleh aspek sumber daya manusia dan aspek prosedur pelaksanaan (15).

Dari beberapa akar permasalahan ketidaklengkapan pengisian rekam medis di RSI Unisma Malang ditetapkan prioritas masalah adalah susunan form RM yang kurang sistematis karena sebagian besar dokter merasa selama ini form RM susunannya belum sistematis dan alternatif solusi adalah membuat rancangan form RM yang terintegrasi. RM terintegrasi (Integrated Health Record Format)yaitu bentuk RM yang menggabungkan dokumentasi yang datang dari berbagai sumber secara saling berkaitan dan mengikuti urutan kronologis yang ketat atau urutan berbalik arah. Kegunaannya adalah untuk memudahkan pemberi pelayanan kesehatan dalam mengikuti pemberian pelayanan dan pengobatan pasien (16). Kejelasan dan efisiensi form bisa menjadi solusi yang tepat karena bermafaat untuk mengurangi kesibukan mengutip atau menyalin kembali keterangan yang sama berulang-ulang, untuk keseragaman atau pembakuan kerja, untuk mempermudah dalam pengklasifikasian data, untuk mempermudah prosedur kerja, sebagai alat perencanaan, dan sebagai alat untuk pengawasan dan evaluasi.

Terdapat hubungan antara susunan form RM yang kurang sistematis dengan ketidaklengkapan pengisian rekam medis. Dokter yang biasanya tergesa-gesa akan merasa kesulitan dalam mengisi dokumen RM pasien karena susunannya yang kurang sistematis. Solusi yang dipilih adalah dengan membuat rancangan form RM terintegrasi. Diharapkan bisa memperkecil masalah ketidaklengkapan pengisian dokumen rekam medis karena form inimudah digunakan, membantu pengumpulan data yang dibutuhkan, terbatas dari item data yang tidak penting, menyajikan data yang mudah dipahami atau ditindak lanjut sehingga bisa meningkatkan mutu pelayanan rekam medis, karena salah satu cara menilai mutu pelayanan rumah sakit, dapat dilihat kualitas rekam medisnya (17).

2. Gafur KMA. Pentingnya Peningkatan Profesionalisme Rekam Medis dalam Upaya Peningkatan Mutu Pelayanan Kesehatan. Jakarta: Kumpulan Makalah Seminar Nasional dalam Kongres dan Rakernas I-III PORMIKI. http://etd.eprints.ums.ac.id [diakses tanggal 20 februari 2015].

3. Hanafiah M and Amri A. Etika Kedokteran dan Hukum 
Kesehatan. Jakarta: EGC; 2007.

4. Menteri Kesehatan Republik Indonesia. Kemenkes: 129/MENKES/SK/II/2012 tentang Standar Pelayanan Minimum (SPM) Rumah Sakit. Jakarta: Kementerian Kesehatan RI; 2012.

5. Pratiwi YD. Analisis Kelengkapan Pengisian Resume Medis Pasien Rawat Inap RSIA Budi Kemuliaan 20082009. [Skripsi]. Universitas Indonesia, Jakarta. 2009.

6. Menteri Kesehatan Republik Indonesia. Permenkes: 269/Menkes/Per/III/2008, Tentang Rekam Medis. Jakarta: Kementerian Kesehatan Rl; 2012.

7. Shofari B. Pengelolaan Sistem Rekam Medik. Semarang: Perhimpunan Organisasi Profesional Perekammedikan, Informastika Kesehatan Indonesia; 2005.

8. Samil RS. Etika Kedokteran Indonesia. Jakarta: Yayasan Bina Pustaka Sarwono Prawirohardjo; 2001.

9. Departemen Kesehatan Republik Indonesia. Buku Pedoman Pencatatan Kegiatan Pelayanan Rumah Sakit. Jakarta: Direktorat Jenderal Pelayanan Medis; 1994.

10. Zaenal S. Analisis Perilaku Dokter Dalam Mengisi Kelengkapan Data Rekam Medis Lembar Resume Rawat Inap di RS Ungaran Tahun 2005. [Tesis]. Universitas Diponegoro, Semarang. 2006.

11. Hamzah A. Analisis Faktor-faktor yang Mempengaruhi Kinerja Dokter dalam Mengisi Kelengkapan Dokumen Rekam Medis Rawat Inap di
Bapelkes RSUD Blambangan Kab Banyuwangi. [Tesis]. Universitas Brawijaya, Malang. 2007.

12. Lembaga Administrasi Negara Republik Indonesia. Pemecahan Masalah dan Pengambilan Keputusan. Jakarta Lembaga Administrasi Negara RI; 2008

13. Sianipar JPG dan Entang HM. Teknik-teknik Analisis Manajemen. Di dalam: Sianipar JPG and Entang HM (Eds). Macam-macam Cara Analisis Manajemen. Jakarta Lembaga Administrasi Negara Rl; 2008.

14. Mawarni D dan Wulandari RD. Identifikasi Ketidaklengkapan Rekam Medis Pasien Rawat Inap Rumah Sakit Muhammadiyah Lamongan. Jurnal Administrasi Kesehatan Indonesia. 2013; 1(2): 192199.

15. Rahmadhani IS, Sugiarsi S, dan Pujihastuti A. Faktor Penyebab Ketidaklengkapan Dokumen Rekam Medis Pasien Rawat Inap dalam Batas Waktu Pelengkapan di Rumah Sakit Umum Daerah Dr. Moewardi Surakarta. Jurnal Kesehatan. 2008; 2(2): 82-88. .

16. Fakultas Kedokteran Universitas Indonesia. Pedoman Rekam Medis Berorentasi Masalah. (Online) 2009. http://kurfak 2005.fk.ui.ac.id/Catatan_Medik_ Berorientasi_Masalah_2009.pdf [diakses tanggal 10 April 2015].

17. Indar I, Indar, dan Naiem MF. Faktor yang Berhubungan dengan Kelengkapan Rekam Medis dI RSUD H. Padjonga Dg. Ngalle Takalar. Jurnal Adminsitrasi \& Kebijakan Kesehatan Indonesia. 2013; 2(2): 10-18. 